\title{
Gecikmiş tanısıyla Hallopeau tipi akrodermatitis kontinua olgusu
}

\section{A case with delayed diagnosis of a Hallopeau type acrodermatitis continua}

\section{Elif Öztürk, Sibel Berksoy Hayta*, Melih Akyol, Sedat Özçelik}

Dermatoloji Kliniği (Dr. Elif Öztürk), Kilis Devlet Hastanesi, TR-79000 Kilis, Dermatoloji Anabilim Dalı (Yrd. Doç. Dr. SB. Hayta, Prof. Dr. M. Akyol, Prof. Dr. S. Özçelik) Cumhuriyet Üniversitesi Tıp Fakültesi, TR-58140 Sivas

Geliş tarihi/Received: 1 Ağustos 2012; Kabul tarihi/Accepted: 31 Temmuz 2013

*İletişim adresi:

Dr. Sibel Berksoy Hayta, Dermatoloji Anabilim Dalı, Cumhuriyet Üniversitesi Tıp Fakültesi, TR58140 Sivas. E-posta: drberksoy@ gmail.com

Sayın editör;

Hallopeau tipi akrodermatitis kontinua (HAK), el ve ayakların nadir görülen steril püstüler erüpsiyonudur. Tekrarlayan püstüller tırnak kaybına ve distal falanksta atrofiye yol açabilir. $\mathrm{Bu}$ yazıda dar uçlu ayakkabı giymenin oluşturduğu travmanın tetiklemiş olabileceğini düşündüğümüz, tanısı gecikmiş bir HAK olgusunu sunuyoruz.

Otuz yedi yaşında erkek hastanın, yaklaşık iki yıldır 3-4 ay ara ile tekrarlayan her iki ayak birinci parmak uçlarında şişlik, kızarıklık, akıntı şikayeti mevcuttu. Hastaya değişik merkezlerde çeşitli topikal ve sistemik ilaçlar (antibakteriyal, antifungal) verilmiş ve bunlardan kısmen fayda görmüştü. Yapılan dermatolojik incelemede her iki ayak birinci parmak tırnaklarında kayıp, tırnak yatağında sarı kahve krutlar, parmak distalinde hafif ödematöz görünüm ve kırmızı-mor renk değişikliği saptandı. Tırnak yatağındaki krutlar kaldırıldığında tırnak yatağı ve çevresinde eritemli zeminde 0,2-0,3 cm çaplı püstüler lezyonlar görüldü (Resim 1a). Hastanın kendisinde ve ailesinde psoriyazis veya ilişkili hastalık yoktu. Hastanın dar uçlu ayakkabı giyme öyküsü varken sigara kullanımı öyküsü yoktu.

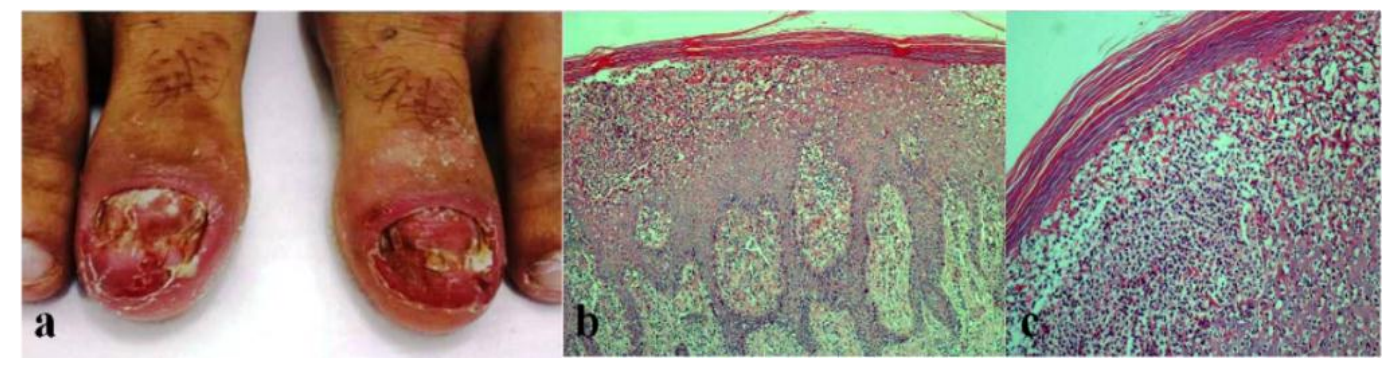

Resim1- a. Ayak tırnaklarında kayıp ve püstüler lezyonlar. b. Hiperkeratoz, subkorneal püstül, epidermal hiperplazi (H\&Ex25). c. Subkorneal spongioform püstül (H\&Ex50).

Hastanın parmağında bulunan püstüllerden alınan örnekler ile yapılan gram boyamada organizma saptanmadi. Alınan örneklerin potasyum hidroksit incelemesinde mantar elemanları gözlenmedi. Yara yeri ve mantar kültüründe üreme olmadı. Hastanın yapılan kan tahlillerinde anormallik yoktu. Radyolojik olarak patoloji saptanmadi.

Alınan deri biyopsisinin histopatolojik incelenmesinde hiperkeratoz, hipogranuloz, belirgin spongioform püstüller, epidermal hiperplazi ve süperfisyal perivasküler nötrofilik infiltrasyon saptandı. Bulgular, püstüler psoriyazis ile uyumlu olarak tanımlandı (Resim 1b-1c). 
Klinik ve histopatolojik bulgular ile hastaya HAK tanısı konuldu. Sigara içimi öyküsü ve belirgin infeksiyon odağı saptanamaması, dar uçlu ayakkabı giyme öyküsünün olması ve lezyonların özellikle her iki ayak birinci parmaklarında lokalize olması nedeniyle ayakkabıya bağlı travmanın hastalığı tetiklediği düşünüldü ve hastaya haftada bir kez 15 mg metotreksat ve folik asit tedavisi başlanarak, ayakkabı seçimi ile ilgili önerilerde bulunuldu. Hastanın bir ay sonraki kontrolünde lezyonlarında düzelme tespit edildi ve takibine devam edildi.

Hallopeau tipi akrodermatitis kontinua, el ve ayak parmaklarının steril püstüller, atrofik deri değişiklikleri, onikodistrofi ve osteolizisi ile karakterize nadir ve kronik akropüstüler erüpsüyonudur. İlk olarak 1890 yılında Hallopeau tarafından tanımlanmıştır [1]. HAK'nın etyolojisi bilinmiyor. Lokalize püstüler psoriyazisin bir varyantı olduğu düşünülmektedir. Travma, kronik infeksiyonlar ve ağır sigara içiciliği ile ilişki saptanmıştır [2]. Akral bölgelerde şiddetli inflamasyon, püstül oluşumu ve tırnak hasarı ile karakterize HAK' da asimetrik birkaç parmak veya tüm parmaklar tutulabilir. El parmaklarında ayak parmaklarına göre daha sık görülür. Tırnak matriksi ve tırnak yatağında püstül oluşumuna bağlı onikodistrofi ve hatta anonişi meydana gelebilir. Zamanla erüpsiyon altındaki yumuşak dokuda skleroz ve distal falankslarda osteolizis meydana gelebilir [3]. HAK tek parmak ile sınırlı olduğu zaman dermatitis repens veya akrodermatitis perstans olarak da bilinir [1]. HAK orta yaş kadınlarda sık görülür fakat, çocuk ve yaşlıları da içeren tüm yaş gruplarında görülebilir [3]. HAK yıllarca lokalize kalır fakat, özellikle yaşlılarda generalize püstüler psoriyazise dönüşebileceği bildirilmiştir [4]. S1klıkla infeksiyon ve travma ile ilişkili bir başlangıç olmasına rağmen her zaman böyle bir epizot olmayabilir veya hatırlanamayabilir. Ayırıcı tanıda kronik bakteriyal, fungal ve viral paronişi, süperinfekte malinite, sekonder infekte kontakt dermatit veya dizhidrotik ekzema düşünülmelidir ve gerekli tetkikler yapılarak bunlar dışlanmalıdır. Histopatolojik olarak püstüler psoriyazis için karakteristik olan subkorneal nötrofilik püstüller görülür [5]. HAK sıklıkla tedavilere dirençlidir, ara sıra dramatik yanıtlar elde edilmiştir. Tedavide tetrasiklin, azitromisin, dapson, topikal kalsipotriol ve betametazon, kolşisin, siklosporin, takrolimus, etanersept, infliksimab, asitretin, metotreksat, prednizolon, ultraviyole A + psoralen (PUVA) gibi immunmodulatörler ve bunların kombinasyonları kullanılarak değişik yanıtlar alınmıştır [6-8]. Darband ultraviyole B (UVB), talidomid + genişband UVB ve adalimumab ile başarıyla tedavi edilen çocuk ve yetişkin olgular bildirilmiştir [3, 6]. Olgumuzda da metotreksat tedavisine iyi yanıt alınmıştır.

Nadir görülülen, sıklıkla farklı tanılarla tedavi edilmeye çalışılarak tanıda gecikmelerin yaşandığı HAK olgularının varlığı unutulmamalıdır. Kronik seyirli benzeri olgularda bu tanının varlığı ve ayakkabıya bağlı travmaların da hastalığı tetikleyebileceği dikkate alınmalıdır.

\section{Kaynaklar}

1. Braun-Falco O, Plewing G, Wolf HH, Burgdorf WHC. Acrodermatitis continua suppurativa. Dermatology. Third Edition. Springer-Verlag, Berlin, 2009: 521.

2. Weisshaar E, Diepgen TL. Successful etanercept therapy in therapy refractory acrodermatitis continua suppurativa Hallopeau. J Dtsch Dermatol Ges 2007; 5: 489-92.

3. Bordignon M, Zattra E, Albertin C, Belloni-Fortina A. Successful treatment of a 9-year-old boy affected by acrodermatitis continua of Hallopeau with targeted ultraviolet B narrow-band phototherapy. Photodermatol Photoimmunol Photomed 2010; 26: 41-3.

4. Yerushalmi J, Grunwald MH, Hallel-Halevy D, Avinoach I, Halevy S. Chronic pustular eruption of the thumbs. Diagnosis: acrodermatitis continua of Hallopeau $(\mathrm{ACH})$. Arch Dermatol 2000; 136: 925-30.

5. Waller JM, Wu JJ, Murase JE, Dyson SW, Kelly KM. Chronically painful right thumb with pustules and onycholysis. Diagnosis: acrodermatitis continua of Hallopeau. Clin Exp Dermatol 2007; 32: 619-20. 
6. Ryan C, Collins P, Kirby B, Rogers S. Treatment of acrodermatitis continua of Hallopeau with adalimumab. Br J Dermatol 2009; 160: 197-228.

7. Brill TJ, Elshorst-Schmidt T, Valesky EM, Kaufmann R, Thaçi D. Successful treatment of acrodermatitis continua of Hallopeau with sequential combination of calcipotriol and tacrolimus ointments. Dermatology 2005; 211: 351-5.

8. Özçelik S, Akyol M, Özel F, Kızgın S, Marufihah M. Püstüler psoriasisli iki kardes olgu ve metotreksatın etkinliği. T Klin J Dermatol 2000; 10:134-8. 